\title{
Ganoderma lucidum inhibits proliferation of human ovarian cancer cells by suppressing VEGF expression and up-regulating the expression of connexin 43
}

Shuyan Dai, , Jingjing Liu, Xiaofei Sun and Ning Wang

\begin{abstract}
Background: Ganoderma lucidum (G. lucidum, Reishimax) is an herbal mushroom known to have inhibitory effect on tumor cell growth. However, the molecular mechanisms responsible for its anti-proliferative effects on the ovarian cancer have not been fully elucidated.

Methods: Human ovarian cancer cells HO 8910 (HOCC) and human primary ovarian cells (HPOC) were treated with G. lucidum. Effects of G. lucidum treatment on cell proliferation were studied by MTT assay. The expression of vascular endothelial growth factor (VEGF) and connexin 43 (Cx43) were measured by immunohistochemistry and real time polymerase chain reaction. To study the molecular mechanism of CX43 mediated anti-tumor activity, small interference RNA (siRNA) was used to knockdown Cx43 expression in HOCC.

Results: G. lucidum treatment resulted in reduced proliferation of HOCC. Inhibition of proliferation was accompanied by a decrease in VEGF expression and increase in Cx43 expression in the cancer cells. The extent of immune-reactivity of $\mathrm{C} 43$ or VEGF in cancer cells were correlated with the concentrations of $\mathrm{G}$. lucidum used for treatment. Furthermore, knockdown of $\mathrm{Cx} 43$ expression in HOCC abrogated the effect of $\mathrm{G}$. lucidum on cell proliferation without alteration of G. lucidum-induced attenuation of VEGF expression.
\end{abstract}

Conclusions: G. lucidum inhibits ovarian cancer by down-regulating the expression of VEGF and up-regulating the downstream Cx43 expression. G. lucidum may be a promising therapeutic agent for the treatment of ovarian cancer.

Keywords: Ganoderma lucidum, Ovarian cancer, Real-time PCR, Immunohistochemistry, Vascular endothelial growth factor (VEGF), Connexin 43 (Cx43)

\section{Background}

Ovarian cancer is the most frequent cause of cancer related death in women [1]. The high mortality can be attributed to late diagnosis and lack of effective treatment especially at later stages of the disease. Dried powder of a medicinal mushroom Ganoderma lucidum has been used in Chinese traditional medicine for over two thousand years. The mushroom is also used as a dietary supplement in other parts of the world. Extracts of the

\footnotetext{
* Correspondence: daishy2014@163.com Department of Obstetrics and Gynecology, The Affiliated Shengjing Hospital, China Medical University, 36 Sanhao Street, Heping district, Shenyang 110004, People's Republic of China
}

(c) 2014 Dai et al.; licensee BioMed Central Ltd. This is an Open Access article distributed under the terms of the Creative Commons Attribution License (http://creativecommons.org/licenses/by/2.0), which permits unrestricted use, distribution, and reproduction in any medium, provided the original work is properly credited. The Creative Commons Public Domain Dedication waiver (http://creativecommons.org/publicdomain/zero/1.0/) applies to the data made available in this article unless otherwise stated.

mushroom are known to have several biological properties including anti-tumor activities on different cancer cells lines.

The anti-cancer activity of G. lucidum is observed at different stages of carcinogenesis. Anti-cancer activity of the mushroom includes cell cycle arrest, induction of apoptosis and autophagy, and suppression of metastasis and angiogenesis [2]. G. lucidum has been shown to exert multiple anti-tumor effects on ovarian cancer cells and enhance the sensitivity of epithelial ovarian cancer (EOC) cells to cisplatin [3,4]. However, the molecular mechanism responsible for the inhibitory effects of G. lucidum on the ovarian cancer has not been fully elucidated. 
Vascular endothelial growth factor (VEGF) is an important regulator of vascular endothelial cell functions during tumor growth. Ovarian cancer cells secrete large amounts of VEGF, which plays a crucial role in the accumulation of ascites fluid, angiogenesis and tumor induced immunosuppression in ovarian cancer patients [5]. Increased expression of VEGF is also associated with poor prognosis in ovarian cancer patients [6,7]. Gap junction is an important cell to cell communication structure playing an important role in physiological functions like cell differentiation, cell growth and tissue homeostasis. Several second messengers, small metabolites, and peptides for basic cell physiological activities are transported through the gap junctions [8]. Several carcinogens were shown to decrease the expression of connexins [9], while enhancement of connexin function had an inhibitory effect on the growth of cancers $[10,11]$. The gap junction gene connexin 43 ( $\mathrm{Cx} 43)$ shows tumorsuppressing effects on various tumors [12]. Decrease in the expression of $\mathrm{Cx} 43$ was shown to decrease the sensitivity of ovarian cancer cells to chemotherapeutic agents. However the molecular mechanism of $\mathrm{Cx} 43$ on suppression of ovarian cancer is not known yet. Some studies have indicated that human ovarian surface epithelial cells and surgical specimens of normal ovary exhibit extensive Cx43 expression, whereas $\mathrm{Cx} 43$ expression in ovarian adenocarcinomas is nearly absent. These findings suggest that the loss of gap junctions and Cx43 are associated with a neoplastic process $[13,14]$. Loss of gap junctional intercellular communication (GJIC) is critical for tumor progression because it allows the cells to escape growth control [15]. A defect in posttranslational phosphorylation of $\mathrm{Cx} 43$ protein is associated with low expression of the $\mathrm{Cx} 43$ gene which may be responsible for the GJIC deficiency in AB1 cells. Increased expression of $\mathrm{Cx} 43$ by gene amplification may restore this phosphorylated $\mathrm{Cx} 43$ protein and reestablish GJIC [16]. It has been reported that VEGF can stimulate the expression of $\mathrm{Cx} 43$ in cardiac myocytes $[17,18]$. G. lucidum extracts are known to inhibit the expression of VEGF in a variety of cancer cell lines but its effect on Cx43 is not known. In the present study, we tested the effect of G. lucidum on amelioration of ovarian cancer and its effect on the expression of VEGF and Cx43.

\section{Methods \\ Materials \\ Reagents}

Cell culture reagents were purchased from Invitrogen (Carlsbad, CA). G. lucidum (Reishimax) was purchased from Pharmanex Guoyao Co. (Wuhan, China). This product was a standard extract of G lucidum, containing $6 \%$ triterpenes and $13.5 \%$ polysaccharides. The same product has been demonstrated to suppress growth of breast cancer cells [19], prevent breast-to-lung cancer metastasis
[20], inhibit adipocyte differentiation, stimulate glucose uptake and activate AMPK [21]. Stock solution was prepared by dissolving the sample in sterile water at a concentration of $50 \mathrm{mg} / \mathrm{ml}$ and stored at $4^{\circ} \mathrm{C}$, as described earlier [19].

\section{Cell culture}

Human ovarian cancer cells HO 8910 (HOCC) were purchased from Shanghai Bluegene Biotech CO., LTD (Shanghai, China). Human primary ovarian cells (HPOC) were purchased from the Institute of Biochemistry and Cell Biology (Shanghai, China). All cells were cultured in RPMI 1640 supplemented with 10\% fetal bovine serum, penicillin $(100 \mathrm{IU} / \mathrm{ml})$, and streptomycin $(100 \mu \mathrm{g} / \mathrm{ml})$.

\section{HOCC and HPOC proliferation assay}

HOCC and HPOC were harvested using 0.05\% trypsin. Cells were suspended $(40,000$ cells $/ \mathrm{ml})$ in DMEM with $20 \%$ FBS, plated onto gelatinized 96-well culture plates $(0.1 \mathrm{ml} /$ well $)$, and incubated at $37^{\circ} \mathrm{C}$ and $5 \% \mathrm{CO} 2$ for 24 hours. The media was replaced with $0.1 \mathrm{ml}$ of DMEM and 5\% FBS with or without the addition of $10 \mathrm{ug} / \mathrm{ml}$ G. lucidum and incubated for 24,48 and $72 \mathrm{~h}$, at $37^{\circ} \mathrm{C}, 5 \%$ $\mathrm{CO}_{2}$. Cell proliferation was determined using MTT assay, mRNA expression and protein levels for Cx43 and VEGF were measured by real time PCR and Western blotting.

\section{Small interference RNA (siRNA) transfection}

Cx43 siRNA and scrambled siRNA siRNA were designed and synthesized by Wuhan Genesil Biotechnology Co (Wuhan, China). The sequences for siRNAs were as follows: Cx43 siRNA: GCTGGTTACTGGCGACAGA; scrambled siRNA: TTCTCCGAACGTGTCACGT [22]. HOCC cells $(40,000$ cells/ml) in DMEM with $20 \%$ FBS, were plated on gelatinized 96-well culture plates $(0.1 \mathrm{ml} /$ well), and incubated at $37^{\circ} \mathrm{C}$ and $5 \% \mathrm{CO} 2$ for $24 \mathrm{~h}$. The media was replaced with $0.1 \mathrm{ml}$ of DMEM and 5\% FBS with the addition of $10 \mathrm{ug} / \mathrm{ml}$ G. lucidum. Cx43 siRNA $(40 \mathrm{nmol} / \mathrm{L})$ or scrambled siRNA was transfected into the cells using Lipofectamine 2000 reagent (Invitrogen, Carlsbad, CA, USA) according to the manufacturer's instructions. The dose of Cx43 siRNA was selected based on a previous study which resulted in maximal knockdown of Cx43 expression in human aortic endothelial cells [22]. HOCC cells treated with $10 \mathrm{ug} / \mathrm{ml}$ G. lucidum alone served as control. After $72 \mathrm{~h}$ incubation at $37^{\circ} \mathrm{C}$ and $5 \% \mathrm{CO} 2$, Cell proliferation was determined using MTT assay, mRNA expression and protein levels for Cx43 and VEGF were measured with real time PCR and Western blotting.

\section{Real time PCR}

Real time PCR was performed using a Stratagene Mx3005P QPCR System instrument (La Jolla, CA, USA) according to 
manufacturer's protocol. RNA was isolated from HOCC and HPOC, followed by cDNA synthesis and data analysis as described previously [23]. Primers used for the real time qPCR were as following: Cx43, 5'-GGGTGA CTGGAGCGCCTTAG-3' and $5^{\prime}$-TTATCTCAATCTGC TTCAAG-3'. VEGF, 4, 5' -AAGGAAGAGG AGAGGG GGCC-3' and 5' - CTCCTCCTTCTGCCATGGGTG -3'; GAPDH, 5' -CCCTTCATTGACCTCAACTAC-3' and 5' CCACCTTCTTGATGTCATCAT-3'. GAPDH was used as an internal control.

\section{Western blotting}

HOCC and HPOC cells were homogenized in RIPA buffer $(150 \mathrm{mM}$ Sodium chloride, 1\% NP-40, 0.5\% sodium deoxycholate, $0.1 \%$ SDS, $50 \mathrm{mM}$ Tris- $\mathrm{HCl}$ (pH 8.0) containing protease inhibitor (Complete Mini Roche). After centrifugation the supernatants were boiled and mixed with an equal volume of sample buffer. Proteins were separated by SDS-PAGE and transferred to a polyvinylidene difluoride membrane (Millipore). The membranes were blocked with $5 \%$ skim milk in TBST $(10 \mathrm{mM}$ Tris (pH 7.5), $100 \mathrm{mM} \mathrm{NaCl}$ and $0.1 \%$ Tween 20) and incubated with primary antibodies 1 in TBST with $0.5 \%$ skim milk overnight at $4^{\circ} \mathrm{C}$. The membrane was treated with primary antibodies and horseradish peroxidase-conjugated goat anti-mouse immunoglobulin $\mathrm{G}$ antibody (1:3000) (Amersham Biosciences) as secondary antibody. Immunoreactive bands were visualized by ECL (GE Healthcare) and quantified by densitometry with Image J software 1.45 (NIH, Bethesda, USA).

\section{Immunohistochemistry}

Goat anti-mouse VEGF antibody (R\&D Systems Inc. Minneapolis, MN. USA) and the goat anti-Cx43 antibody (Santa Cruz Biotechnology Inc., Santa Cruz, CA, USA) were used for immunohistochemical staining for VEGF AND Cx43. The HOCC and HPOC were fixed and processed in $10 \mathrm{mM}$ of sodium citrate buffer $(\mathrm{pH} 7.6)$ in a microwave oven for four min twice at $70 \%$ power. Endogenous peroxidase was blocked by $5 \%$ hydrogen peroxide for $5 \mathrm{~min}$. Nonspecific binding sites were blocked by $2 \%$ normal horse serum for $20 \mathrm{~min}$. The samples were incubated with the primary antibodies for $60 \mathrm{~min}$. Immunoreactivity was visualized by using DAKO Envision HRP System (1:10,000 dilution) (DAKO, Carpinteria, California, USA). Immunoreactivity was quantitatively evaluated using NIH image program. A score of 0-300 was calculated as the product of the intensity score and the percent of immunoreactivity.

\section{Statistical analysis}

The association between the levels of immunoreactivity of Cx43 or VEGF and the concentration of G. lucidum was compared by one-way analysis of variance (ANOVA).
The post hoc test used was Fisher's protected least significant difference (LSD) test. Spearman's rank correlation coefficient was used to identify the strength of correlation between the levels of the Cx43 or VEGF and the concentration of G. lucidum. Data was analyzed using Statview 5.0 software (Abacus systems, Berkley CA) with a $p$ value of $<0.05$ accepted as significant.

\section{Results}

\section{HOCC and HPOC growth curve}

The HOCC and HPOC were cultured in DMEM with 1 $5 \%$ FBS for 24, 48 and $72 \mathrm{~h}$. The results for cell proliferation are shown in Figure 1. G. lucidum inhibited the growth of HPOC by less than $10 \%$ while it inhibited the growth of HOCC by up to $60 \%$ after 3 days of culture. These results suggest that G. lucidum effectively prevents the cell proliferation in HOCC.

\section{G. lucidum increases Cx43 mRNA expression and reduces VEGF mRNA expression}

The expression of $\mathrm{Cx} 43 \mathrm{mRNA}$ increased after 3 days of culture $(\mathrm{P}<0.05)$ in both untreated and G. lucidumtreated groups, compared with day 0 in HPOC cells (Figure 2). The VEGF mRNA expression in untreated group remained constant during 3 days of culture. However, VEGF mRNA expression in G.lucidum-treated group was found to be significantly reduced on day 3 in the HPOC cells. The expression of Cx43 mRNA decreased in the untreated group at day 2 and day 3 in HOCC cells. In contrast, the Cx43 mRNA expression in G. lucidumtreated group significantly increased from day 1 and remained at a high level on day 3. The VEGF mRNA expression in untreated group significantly increased by day 2 and continued to increase on day 3 . However, no significant change in VEGF mRNA expression was observed in G. lucidum-treated group during the 3 days

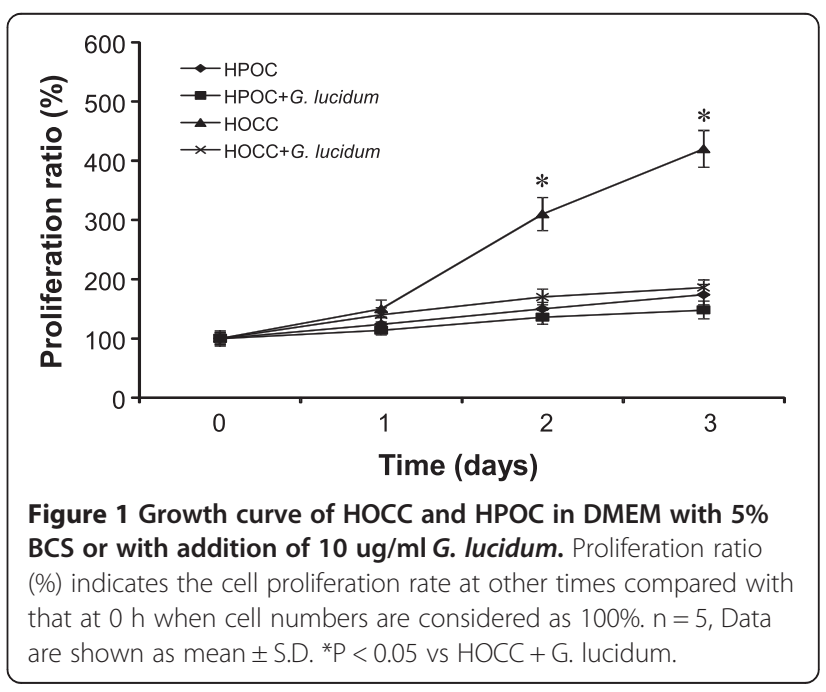




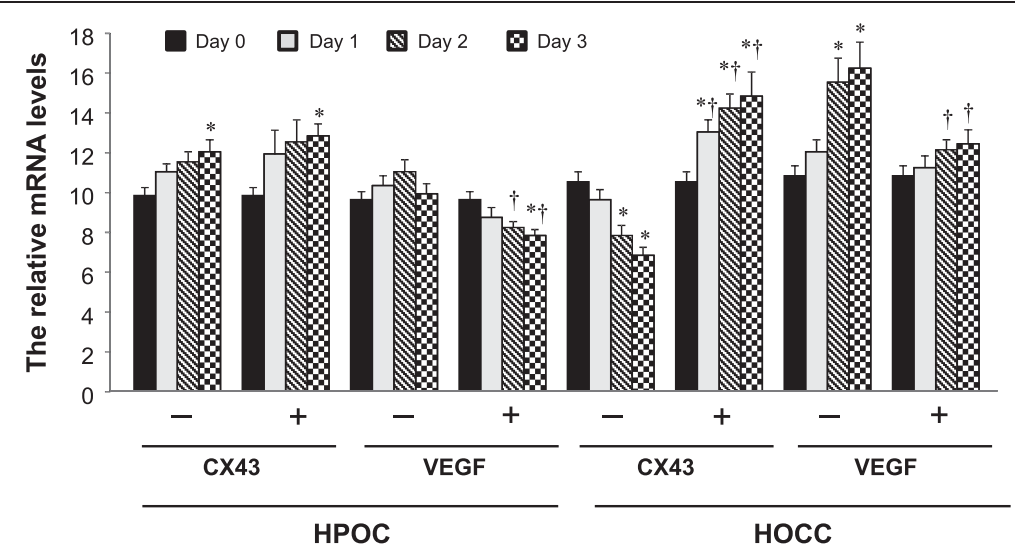

Figure 2 The relative levels of Cx43 and VEGF mRNA in HOCC and HPOC. "-" stands for untreated group (control). "+" stands for G. lucidum-treated group at dose of $10 \mathrm{ug} / \mathrm{ml}$. Data are shown as mean \pm S.D. of three independent experiments. All the cells were treated with G. lucidum for successive 3 days. ${ }^{*} P<0.05$ vs respective day $0 ;+P<0.05$ vs corresponding untreated group.

of culture. These data indicate that G. lucidum treatment effectively increases Cx43 mRNA expression and inhibits VEGF mRNA expression in HOCC but not in HPCC.

\section{G. lucidum increases Cx43 protein expression and decreases VEGF protein expression}

In untreated groups, the expression of $\mathrm{Cx} 43$ protein increased in HPOC, whereas it decreased in HOCC during 3 days of culture (Figures 3 and 4). The VEGF protein expression increased in both HPOC and HOCC at day 3 . In treated group, the $\mathrm{Cx} 43$ protein expression was significantly augmented in both HPOC and HOCC at day 3. The increase in $\mathrm{Cx} 43$ protein expression was more pronounced in HOCC compared with HPOC. As expected, the VEGF protein expression was efficiently suppressed in both HOCC and HPOC treated with $G$ lucidum. Thus, these results are consistent with mRNA data from our study and other report in the ovarian cancer cell [14], suggesting that HOCC are sensitive to G. lucidum treatment.
The effects of $G$. lucidum on the protein levels of Cx43 and VEGF in a dose-dependent way in HOCC

In HPOC, increase in G. lucidum concentration did not induce significant changes in protein level of $\mathrm{Cx} 43$ or VEGF (Figure 5). In contrast, increase in G. lucidum concentration increased protein level of $\mathrm{Cx} 43$ and decreased protein level of VEGF in a dose dependent manner in HOCC. Furthermore, Spearman's rank correlation coefficient showed a significant correlation between the concentration of G. lucidum and protein level of Cx43 or VEGF in HOCC but not in HPOC (Figure 6).

Knockdown of Cx43 abrogates the effect of G. lucidum on HOCC proliferation without alteration of G. lucidum-induced attenuation of VEGF

To further explore the molecular mechanism involved in the down-regulation of VEGF expression and up-regulation of Cx43 expression by G. lucidum, we examined the effects of knockdown of Cx43 on VEGF expression and cell proliferation in HOCC treated with G. lucidum. As shown in

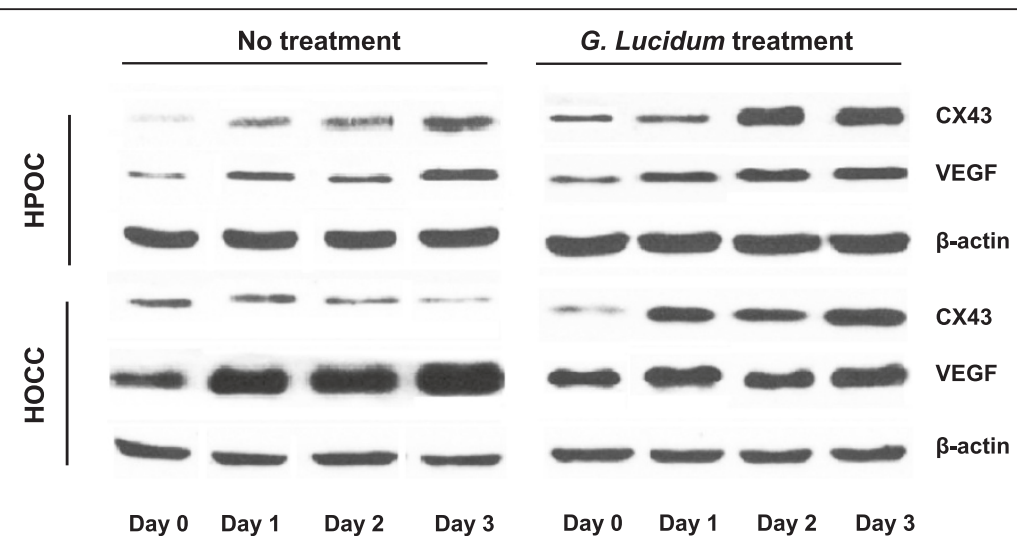

Figure 3 Representative Western blots for Cx43 and VEGF in HOCC and HPOC treated with or without G. lucidum. 


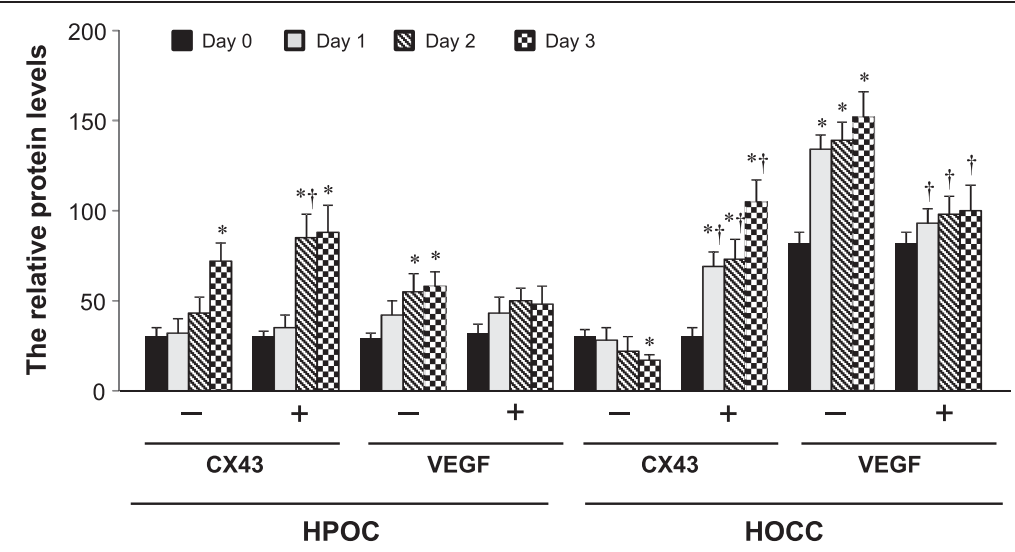

Figure 4 Quantitative comparison of protein levels for Cx43 and VEGF in HOCC and HPOC treated with or without G. lucidum. Data are shown as mean \pm S.D. of three independent experiments. ${ }^{*} P<0.05$ vs respective day $0 ;+P<0.05$ vs corresponding untreated group.

Figures 7 and 8, there were no differences in mRNA expression and protein levels for Cx43 and VEGF (Figure 7), and cell proliferation (Figure 8) at day 0. G. lucidum treatment significantly increased Cx43 expression, and prevented the expression of VEGF and cell proliferation in control group at day 3. Cx43 siRNA, but not scrambled siRNA, markedly reduced $\mathrm{Cx} 43$ expression at day 3 in HOCC treated with G. lucidum. Reduction in $\mathrm{Cx} 43$ expression by Cx43 siRNA did not alter G. luciduminduced attenuation of VEGF, but abrogated the beneficial effects of G. lucidum on cell proliferation.

\section{Discussion}

Ovarian cancer is the most frequent cause of gynecologic cancer-related death in women [24]. Clinical and pathological diagnosis carried out by various scans and tumor biopsies are key factors for correct and timely treatment [25-27]. Few cancer biomarkers are also currently used for population screening, disease diagnosis, prognosis, monitoring of therapy and prediction of therapeutic response [28].

The anticancer effects of G. lucidum have been attributed to its bioactive compounds including polysaccharides and a group of triterpenes [3]. The precise molecular mechanism by which $G$. lucidum exerts its anticancer properties on ovarian cancer remains incompletely understood. Our present study suggests that G. lucidum treatment reduced the expression of VEGF and increased the expression of $\mathrm{Cx} 43$, in a dose dependent manner, which was accompanied by decreased cell proliferation in HOCC. More importantly, we found that knockdown of Cx43 with siRNA abrogated the beneficial
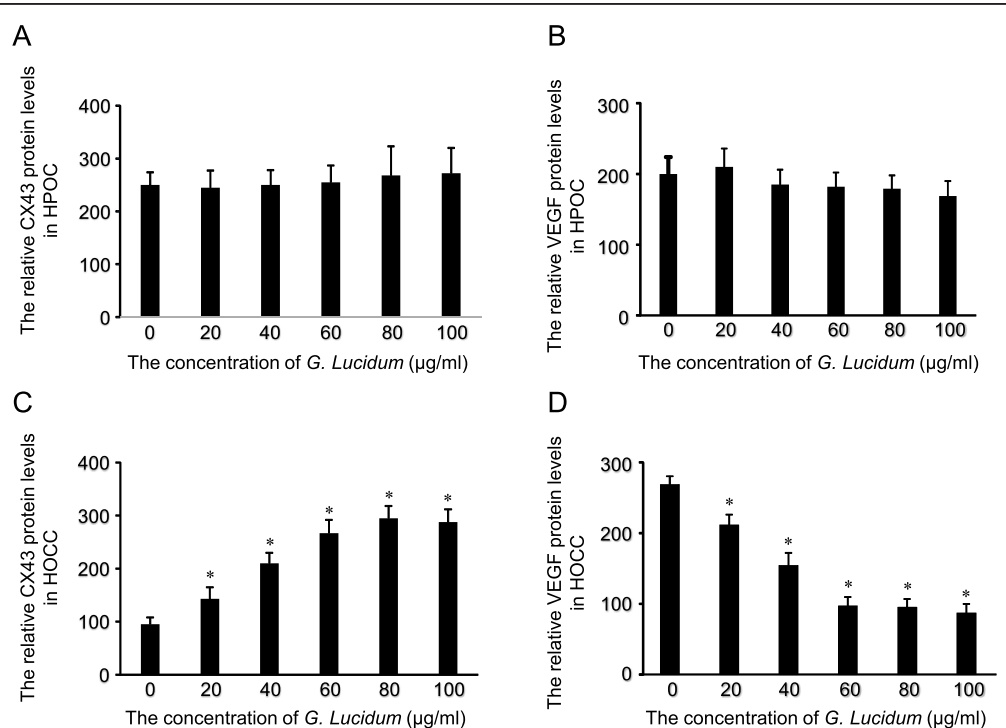

Figure 5 Dose-dependent effects of G. lucidum on Cx43 (A and C) or VEGF (B and D) protein levels in HOCC and HPOC. *P $<0.05$ VS control $(0 \mu \mathrm{g} / \mathrm{ml})$. 

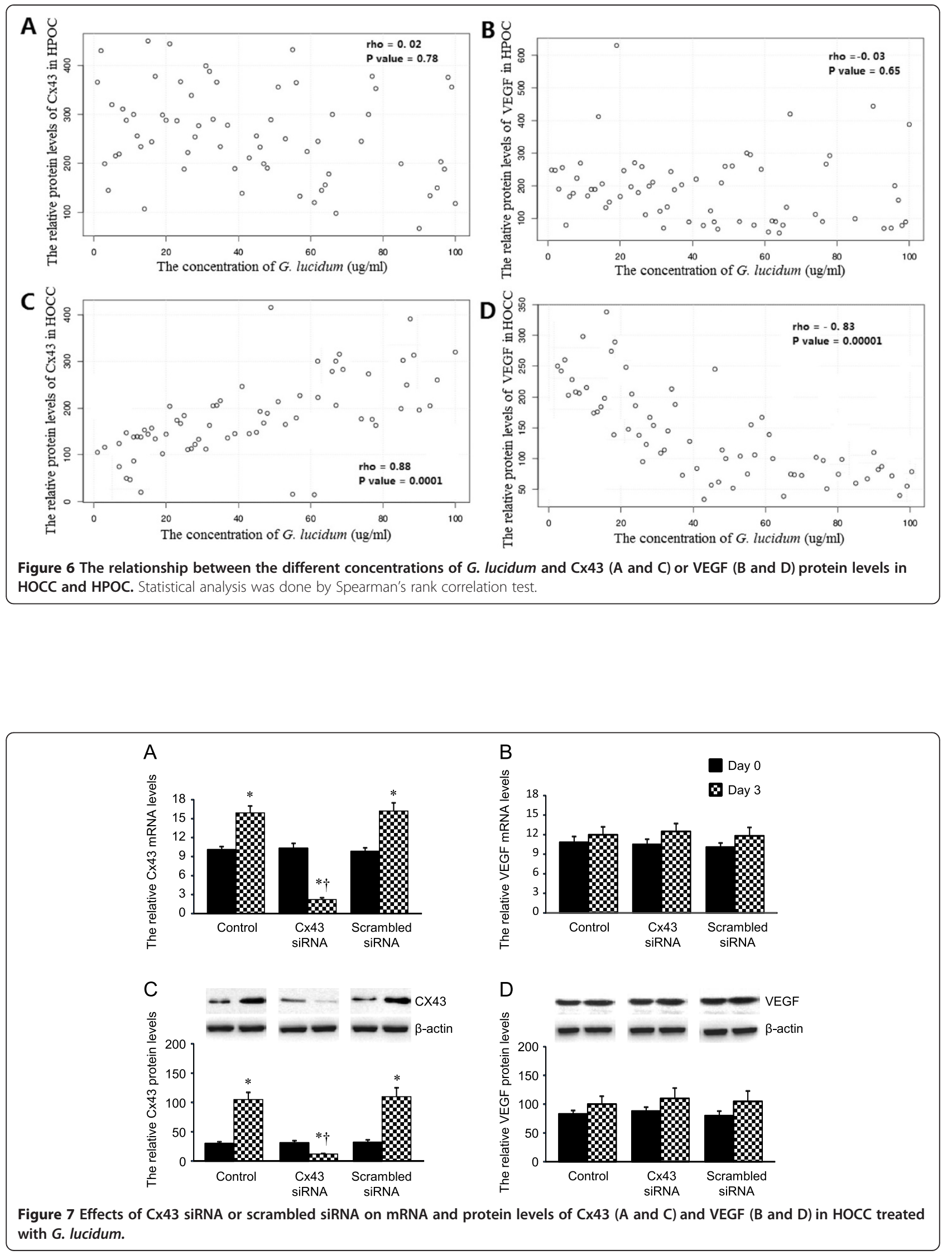


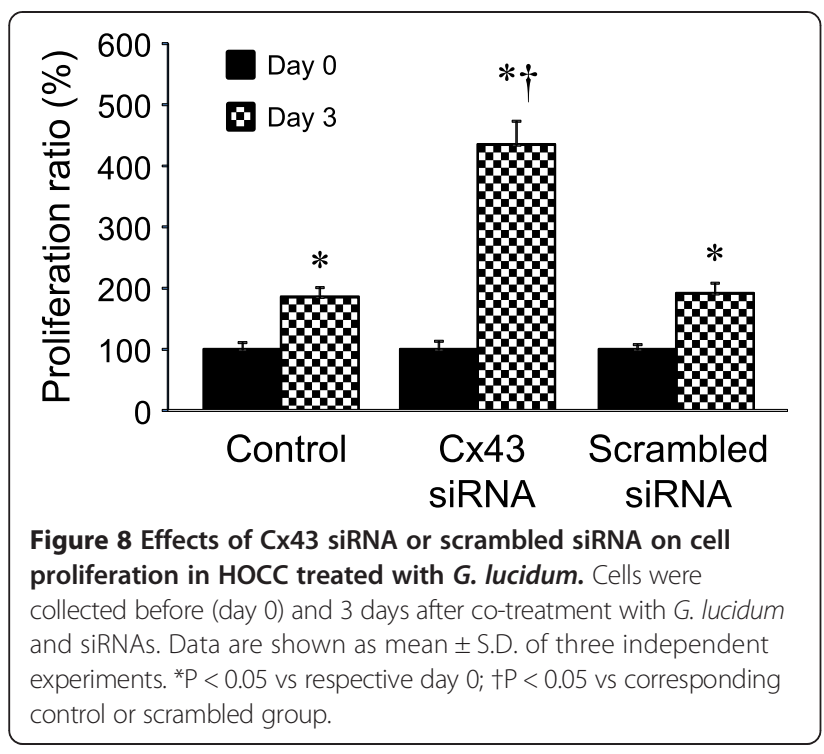

effect of G. lucidum on cell proliferation without altering the G. lucidum-induced attenuation of VEGF in HOCC. These findings suggest that VEGF acts downstream $\mathrm{Cx} 43$ to mediate cell proliferation. G. lucidum exhibits an anticancer effect by up-regulating $\mathrm{Cx} 43$ expression via down-regulation of VEGF expression. Previous studies showed that VEGF increased the protein expression of $\mathrm{Cx} 43$ in endothelial cells and cardiac myocytes $[17,18]$. The discrepancy between our results and others might be due to differences in cell type and treatment method.

Our results indicate that CX43 and VEGF play important roles in the genesis and development of ovarian cancer. Measurements of CX43 and VEGF may also be useful in evaluating effects of treatment. Cx43 is one of the major gap junction proteins which are important for intercellular communication, cell homeostasis and proliferation [29]. VEGF may be a useful serological biomarker for clinical diagnosis and prognosis of ovarian cancer, follow-up of ovarian tumor metastasis and for monitoring the efficacy of therapy in patients with ovarian carcinomas [30]. Thus, the combination of Cx43 and VEGF may provide better diagnosis of ovarian cancer. It is known that healthy subjects have higher expression of Cx43 than patients with ovarian cancer. Our data suggests that $\mathrm{Cx} 43 \mathrm{im}$ munological activity could be used as an ancillary study in the cases that are clinically suspicious for primary ovarian malignancy.

A major limitation of the present study should be acknowledged. The effect of G. lucidum on cell proliferation in HOCC was compared with untreated HOCC and HPOC. However, HPOC cells did not proliferate with the same intensity as HOCC cells. Nevertheless, the decreased cell proliferation was clearly observed in $G$. lucidum-treated HOCC, indicating anticancer action of G. lucidum in ovarian cancer.

\section{Conclusions}

In conclusion, the present study demonstrates that G. lucidum inhibits ovarian cancer by down-regulating the expression of VEGF and up-regulating the downstream Cx43 expression. G. lucidum may be a promising therapeutic agent for the treatment of human ovarian cancer.

Competing interests

The authors declare that they have no competing interests.

\section{Authors' contributions}

All authors have read and approved the final manuscript. SD and NW designed the experiment, analyzed the data and prepared the manuscript. $J L$ and XS performed the experiments.

\section{Acknowledgements}

We thank Dr. Tao Song for excellent technical assistance in molecular studies. This work was supported by Liaoning Science and Technology Foundation (No. 2008225009-22 to SD) and Shenyang Science and Technology Foundation (No. F14-158-9-41 to SD).

Received: 1 October 2013 Accepted: 27 October 2014

Published: 5 November 2014

\section{References}

1. Jemal A, Bray F, Center MM, Ferlay J, Ward E, Forman D: Global cancer statistics. CA Cancer J Clin 2011, 61(2):69-90.

2. Wu GS, Guo JJ, Bao JL, Li XW, Chen XP, Lu JJ, Wang YT: Anti-cancer properties of triterpenoids isolated from Ganoderma lucidum - a review. Expert Opin Investig Drugs 2013, 22(8):981-992.

3. Hsieh T-C, Wu JM: Suppression of proliferation and oxidative stress 1 by extracts of Ganoderma lucidum in the ovarian cancer cell line OVCAR-3. Int J Mol Med 2011, 28(6):1065-1069.

4. Zhao S, Ye G, Fu G, Cheng J-X, Yang BB, Peng C: Ganoderma lucidum exerts anti-tumor effects on ovarian cancer cells and enhances their sensitivity to cisplatin. Int J Oncol 2011, 38(5):1319-1327.

5. Santin A, Hermonat P, Ravaggi A, Cannon M, Pecorelli S, Parham G: Secretion of vascular endothelial growth factor in ovarian cancer. Eur J Gynaecol Oncol 1999, 20(3):177-181.

6. Mesiano S, Ferrara N, Jaffe RB: Role of vascular endothelial growth factor in ovarian cancer: inhibition of ascites formation by immunoneutralization. Am J pathol 1998, 153(4):1249-1256.

7. Huang S, Robinson JB, DeGuzman A, Bucana CD, Fidler IJ: Blockade of nuclear factor- $\mathrm{KB}$ signaling inhibits angiogenesis and tumorigenicity of human ovarian cancer cells by suppressing expression of vascular endothelial growth factor and interleukin 8. Cancer Res 2000, 60(19):5334-5339.

8. Goodenough DA, Goliger JA, Paul DL: Connexins, connexons, and intercellular communication. Annu Rev Biochem 1996, 65:475-502.

9. Vinken M, de Kock J, Oliveira AG, Menezes GB, Cogliati B, Dagli ML, Vanhaecke T, Rogiers V: Modifications in connexin expression in liver development and cancer. Cell Commun Adhes 2012, 19(3-4):55-62.

10. Sun Y, Zhao X, Yao Y, Qi X, Yuan Y, Hu Y: Connexin 43 interacts with Bax to regulate apoptosis of pancreatic cancer through a gap junction-independent pathway. Int J Oncol 2012, 41(3):941-948.

11. Li Z, Zhou Z, Welch DR, Donahue HJ: Expressing connexin 43 in breast cancer cells reduces their metastasis to lungs. Clin Exp Metastasis 2008, 25(8):893-901.

12. Zhang YW, Kaneda M, Morita I: The gap junction-independent tumor-suppressing effect of connexin 43. J Biol Chem 2003, 278(45):44852-44856.

13. Corteggio A, Florio J, Roperto F, Borzacchiello G: Expression of gap junction protein connexin 43 in bovine urinary bladder tumours. J Comp Pathol 2011, 144(1):86-90. 
14. Umhauer S, Ruch RJ, Fanning J: Gap junctional intercellular

communication and connexin 43 expression in ovarian carcinoma. Am J Obstet Gynecol 2000, 182(5):999-1000.

15. Spinella F, Rosano L, Di Castro V, Nicotra MR, Natali PG, Bagnato A: Endothelin-1 decreases gap junctional intercellular communication by inducing phosphorylation of connexin 43 in human ovarian carcinoma cells. J Biol Chem 2003, 278(42):41294-41301.

16. Jou YS, Matesic D, Dupont E, Lu SC, Rupp HL, Madhukar BV, Oh SY, Trosko $\mathrm{JE}$, Chang CC: Restoration of gap-junctional intercellular communication in a communication-deficient rat liver cell mutant by transfection with connexin 43 cDNA. Mol Carcinog 1993, 8(4):234-244.

17. Pimentel RC, Yamada KA, Kléber AG, Saffitz JE: Autocrine regulation of myocyte Cx43 expression by VEGF. Circ Res 2002, 90(6):671-677.

18. Iyer RK, Odedra D, Chiu LL, Vunjak-Novakovic G, Radisic M: Vascular endothelial growth factor secretion by nonmyocytes modulates Connexin-43 levels in cardiac organoids. Tissue Eng Part A 2012, 18(17-18):1771-1783.

19. Jiang J, Slivova V, Harvey K, Valachovicova T, Sliva D: Ganoderma lucidum suppresses growth of breast cancer cells through the inhibition of Akt/ NF-kappaB signaling. Nutr Cancer 2004, 49(2):209-216.

20. Loganathan J, Jiang J, Smith A, Jedinak A, Thyagarajan-Sahu A, Sandusky GE, Nakshatri H, Sliva D: The mushroom Ganoderma lucidum suppresses breast-to-lung cancer metastasis through the inhibition of pro-invasive genes. Int J Oncol 2014, 44(6):2009-2015.

21. Thyagarajan-Sahu A, Lane B, Sliva D: ReishiMax, mushroom based dietary supplement, inhibits adipocyte differentiation, stimulates glucose uptake and activates AMPK. BMC Complement Altern Med. 2011, 11:74.

22. Wang $\mathrm{HH}$, Kung $\mathrm{Cl}$, Tseng $\mathrm{YY}$, Lin $\mathrm{YC}$, Chen $\mathrm{CH}$, Tsai $\mathrm{CH}$, Yeh HI: Activation of endothelial cells to pathological status by down-regulation of connexin43. Cardiovasc Res 2008, 79(3):509-518.

23. Peterson SM, Freeman JL: RNA isolation from embryonic zebrafish and cDNA synthesis for gene expression analysis. J Vis Exp 2009, 30:1470

24. Jayson GC, Kohn EC, Kitchener HC, Ledermann JA: Ovarian cancer. Lancet 2014, 384(9951):1376-1388.

25. Kim HW, Won KS, Zeon SK, Ahn BC, Gayed IW: Peritoneal carcinomatosis in patients with ovarian cancer: enhanced CT versus 18 F-FDG PET/CT. Clin Nucl Med 2013, 38(2):93-97.

26. Zytoon AA, Murakami K, Eid H, El-Gammal M: High impact of FDG-PET/CT in diagnostic strategies for ovarian cancer. Acta Radio/ 2013, 54(3):340-348.

27. Klostergaard J, Parga K, Raptis RG: Current and future applications of magnetic resonance imaging (MRI) to breast and ovarian cancer patient management. P R Health Sci J 2010, 29(3):223-231.

28. Diamandis EP: Mass spectrometry as a diagnostic and a cancer biomarker discovery tool opportunities and potential limitations. Mol Cell Proteomics 2004, 3(4):367-378

29. Tekpli X, Rivedal E, Gorria M, Landvik NE, Rissel M, Dimanche-Boitrel MT, Baffet G, Holme JA, Lagadic-Gossmann D: The B[a]P-increased intercellular communication via translocation of connexin-43 into gap junctions reduces apoptosis. Toxicol Appl Pharmacol 2010, 242(2):231-240.

30. Li L, Wang L, Zhang W, Tang B, Zhang J, Song H, Yao D, Tang Y, Chen X, Yang Z, Wang G, Li X, Zhao J, Ding H, Reed E, Li QQ: Correlation of serum VEGF levels with clinical stage, therapy efficacy, tumor metastasis and patient survival in ovarian cancer. Anticancer Res 2004, 24(3b):1973-1979.

doi:10.1186/1472-6882-14-434

Cite this article as: Dai et al:: Ganoderma lucidum inhibits proliferation of human ovarian cancer cells by suppressing VEGF expression and up-regulating the expression of connexin 43. BMC Complementary and Alternative Medicine 2014 14:434.

\section{Submit your next manuscript to BioMed Central and take full advantage of:}

- Convenient online submission

- Thorough peer review

- No space constraints or color figure charges

- Immediate publication on acceptance

- Inclusion in PubMed, CAS, Scopus and Google Scholar

- Research which is freely available for redistribution

Submit your manuscript at www.biomedcentral.com/submit
Ciomed Central 